$$
\begin{aligned}
& \text { Gypsophia hispida } \\
& \text { عطيه نز ادفلاطورى "و مصطفى اسدى } \\
& \text { دريافت: } \\
& \text { 'بخش تحقيقات رستى ها، مؤسسه تحقيقات گياهيزشكى كشور، سازمان تحقيقات، آموزش و ترويج كشاورزى، تهران، ايران }
\end{aligned}
$$

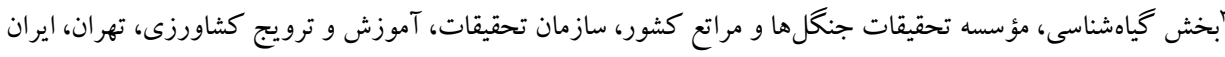

$$
\begin{aligned}
& \text { a.falatoury@areeo.com مسئول مكاتبات }
\end{aligned}
$$

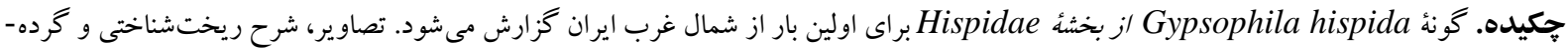

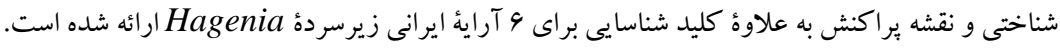

$$
\begin{aligned}
& \text { وازههاى كليدى. تر كيه، خاورميانه، گجدوست، ميخك سانان، ميخكىها }
\end{aligned}
$$

\title{
Gypsophila hispida, A New record for flora of Iran
}

\author{
Atiye Nejad Falatoury ${ }^{1 *} \&$ Mostafa Assadi ${ }^{2}$ \\ Received: 05.07.2018 / Revised: 15.07.2018 / Accepted: 26.08.2018/ Published: 21.12.2018
}

\author{
${ }^{1}$ Iranian Research Institute of Plant Protection, Agricultural Research, Education and Extension Organization (AREEO), \\ Tehran, Iran \\ ${ }^{2}$ Research Institute of Forests and Rangelands, Agricultural Research, Education and Extension Organization (AREEO), \\ Tehran, Iran \\ *Correspondent author: a.falatoury@areeo.com
}

Abstract. Gypsophila hispida, sect. Hispidae, is reported for the first time from NW Iran. Illustrations, morphological and palynological descriptions and distribution are provided in detail, along with a key for the six taxa of subgen. Hagenia from Iran.

Keywords. baby's-breath, Caryophylloideae, Caryophyllales, Middle East, Turkey

\section{INTRODUCTION}

Genus Gypsophila L. (Linnaeus, 1753: 406) (baby's-breath in English), a member of the Pink family (Caryophyllaceae; "Mikhakian" in Persian), with approximately 150 species (Mabberley, 2008: 383 ), is the fourth largest genus of the subfamily Caryophylloideae Rabeler \& Bittrich. and the second largest genus of the tribe Caryophylleae (Rabeler \& Bittrich, 1993: 862). Iran is the second main diversity center of Gypsophila with 38 species (Nejad Falatoury et al., 2015a, b; 2016a,b,c, 2017). In recent decades, some new taxa of Gypsophila have been reported from Turkey and Iran (Mozaffarian, 1991; Ataşlar and Ocak, 2005; Mozaffariann, 2008; Budak, 2012; Y1ldırıml, 2012; Hamzaoğlu, 2012; Koç, 2013; Nejad Falatoury et al., 2015a, b; Armağan, 2016; Nejad Falatoury et al., 2016a, b, c and Armağan et al., 2017). In this paper a new record of the genus Gypsophila subgenus Hagenia (Moenche) Fenzl sect. Hispidae Boiss. is described from West Azerbaijan Province, North West of Iran. This species was previously recorded from East of Turkey and South of Transcaucasia (Schischkin, 1936; Barkoudah, 1962; HuberMorath, 1967; Davis et al., 1988 and Ataşlar, 2000). In addition to the morphology of G. hispida, its palynological characteristics were also discussed. The pollen grains of Gypsophila taxa are monade, apolar, pantoporate with 12 pores, rounded polyhedral, tectate with granulate microechinatemicroperforate ornamentation. 
Pores are annulate, operculate. Pollen grains size (20.7-32 $\mu \mathrm{m})$, operculum diameter $(1.6-6 \mu \mathrm{m})$, Distance between pores $(2.3-7 \mu \mathrm{m})$ and operculum thickness are variable among taxa (Nejad Falatoury et al., 2017).

\section{MATERIALS AND METHODS}

Samples of seeds and flowers were scanned by means of a Dino-Lite-AM413T digital microscope. Pollen and seed samples were scanned by means of a KYKY-EM3200 SEM. The pollen morphology follows the terminology by Punt et al. (2007) and Ataşlar et al. (2009), while we followed Yildiz (2002) and Amini et al for the seeds. (2011). Relevant sources of literature were also considered (Schischkin, 1936; Barkoudah, 1962; HuberMorath, 1967; Davis et al., 1988; Rechinger, 1988; Ataşlar, 2000).

\section{RESULTS AND DISSCUSION}

Subgenus Hagenia (Moenche) Fenzl includes nearly 10 species over the world. It includes six taxa, in two sections, in Iran (Barkoudah, 1962; Huber-Morath, 1967; Davis et al., 1988; Rechinger, 1988; Ataşlar, 2000; Nejad Falatoury et al., 2015b, 2016c). G. hispida Boiss. belongs to sect. Hispidae (Schischk.) Rech.f.

Gypsophila subgen. Hagenia (Moenche) Fenzl in Endl. Gen. Plant. 1: 972 (1840).

Type species: Gypsophila pilosa Huds.

Description: Annual or perennial plants. Inflorescence compound dichasial. Bracts foliaceous rarely with scaroius margins. Calyx more or less campanulate-tubular. Petals length 1.5 to 3 times of calyx length, with distinctive lamina and narrower and longer claw. Ovules 4 to 24 . Seeds nearly $1.5 \mathrm{~mm}$.

Gypsophila sect. Hispidae (Schischk.) Rech.f., Fl. Iranica 163: 241 (1988).

Type species: Gypsophila fedtschenkoana Schischk.

Perennial plants, glandular hairy. Leaves ovate to lanceolate. Inflorescence with many flowers. Calyx usually campanulate-tubular, with 4 to $10 \mathrm{~mm}$. length and rarely shorter.

G. hispida Boiss., Diagn. ser. 1 (I): 11 (1842). (Fig. 1,2)

Syn: G. ixodes Hausskn. ex Bornm. in Beih. Bot. Centr. 28(2): 137 (1911); G. xanthina Bornm. \& Woron. in Monit. Jard. Bot. Tiflis 32: 1 (1914).
Type: Turkey: Cappadocia, along the Euphrates, Aucher 549, holotype G-Boiss photo!

Description: Perennial. Stems several, branched in the upper part, erect, 30-40 cm long, yellowish green, glabrous below, with long glandular hairs above. Internodes 1-5 cm often 3-4 cm long. Lower leaves 20-50 × 2-7 mm, narrow lanceolate, narrowed at the base, glabrous; upper leaves 15-90 $\times 2-17 \mathrm{~mm}$, lanceolate to narrow lanceolate, acute or apiculate; only one to three leaves near the inflorescence glandular-hairy. Inflorescence lax, compound dichasial, glandular-hispid, large, manyflowered. Bracts 1-3 mm long, lanceolate, acuminate, green with scarious margins. Pedicels 520 often $10 \mathrm{~mm}$ long. Calyx, 5-ribbed, campanulate-tubular, 4-6 $\mathrm{mm}$ long, densely glandular-hispid, incised nearly to the middle; teeth ovate, obtuse; green bands twise as broad as the scarious intervals, with crowded crystals. Petals 8$12 \mathrm{~mm}$ long, cuneate, emarginate to sinuate, pale yellow (cream) Stamens 10, shorter than calyx. Ovary globose, with two long styles with terminal stigmatic surface. Ovules 12-16. Capsule ovate, 3.5-4.5 mm long, splitting into 4 valves, with 4-5 seeds. Seeds reniform, with marginal hilum, warty, with black and glossy surface. In terms of exomorphology, the surface of the seed is constructed of regularly arranged polygonal or elongate cells with zip shaped margins and convex periclinal walls with acute papillae, 1.3-1.4 × 1.41.5 mm. (Fig. 3)

Distribution and Habitat - This species has been collected from West Azerbaijan Province, North West of Iran (Fig. 4). The species could be found on limestone slopes and rocks at an altitude of $1100-2150 \mathrm{~m}$.

Phenology - The flowering and fruiting materials were collected from June to July.

Specimens examined (Paratypes):-IRAN. West Azerbaijan Province: Khoy, Razi (border of Turkey), 2050m, 9 July 1991, Mozaffarian 69966 (TARI!); - Turkey. Kars province, 7 June 1913, Woronow 12307 (LE!).

\section{Pollen morphology}

Monade, apolar, rounded polyhedral-spheroidal, 28.4-28.6 $\mu \mathrm{m}$. Grains pantoporate. Pores 2.9-3.4 $\mu \mathrm{m}$. in diameter, annulate. Distance between pores (without annulus) 3.6-4.4 $\mu \mathrm{m}$. Annulus with granules, operculate. Ornamentation is nanoechinate-nanoperforate (Fig. 3 E, F). 


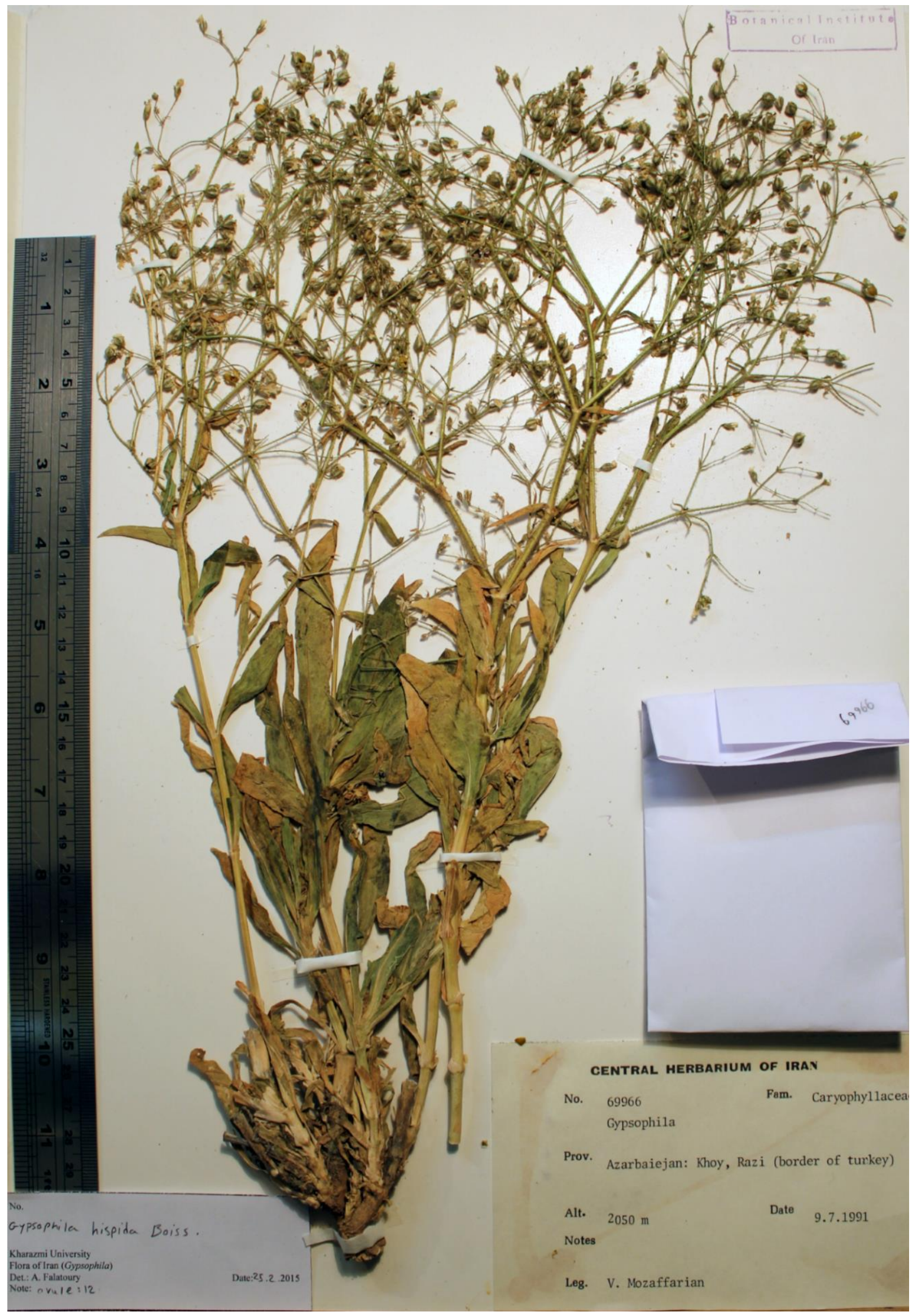

Fig. 1. Gypsophila hispida (V. Mozaffarian 69966, TARI!). 


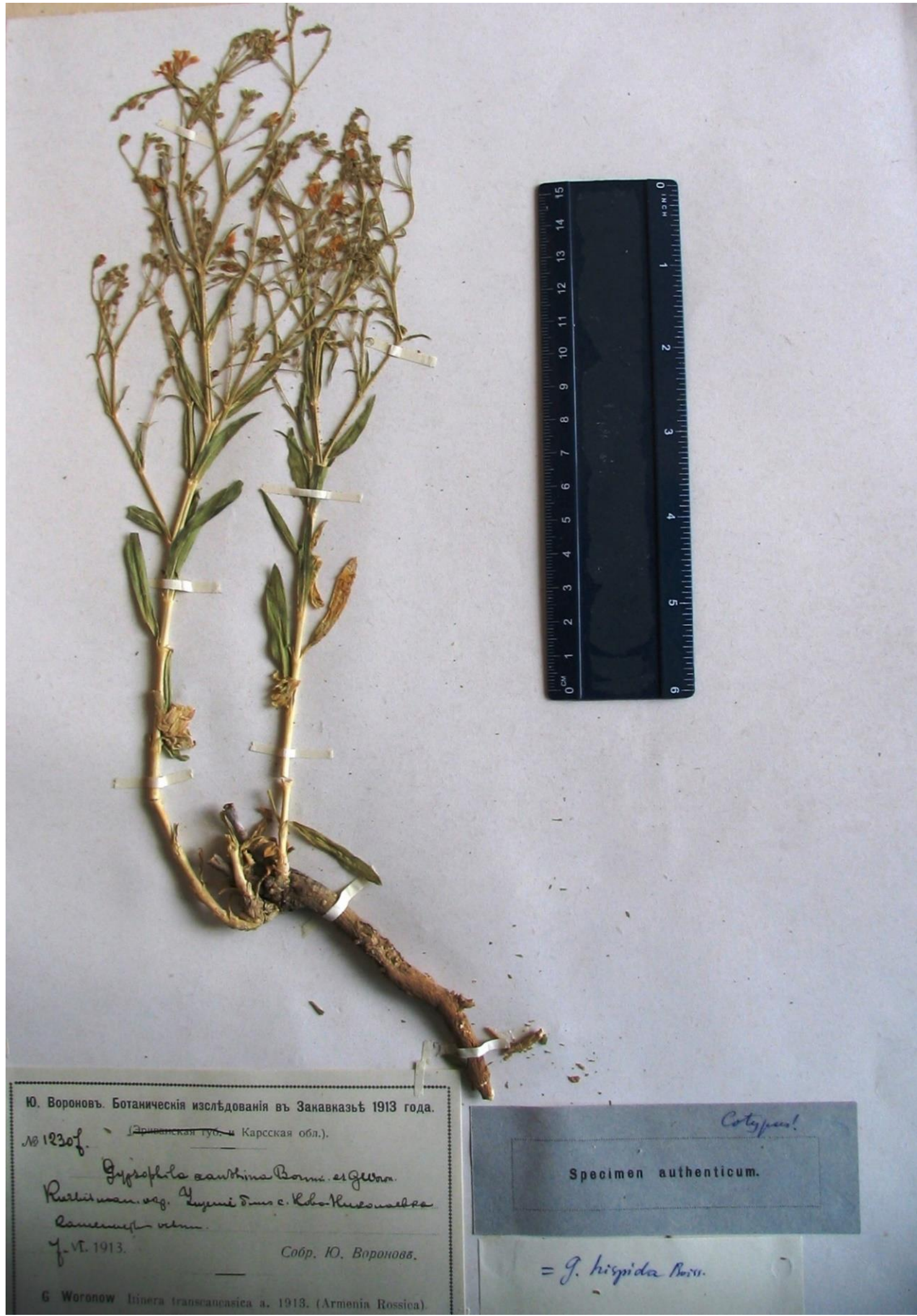

Fig. 2. Syntype of Gypsophila xanthina (Woronow 12307, LE!). 


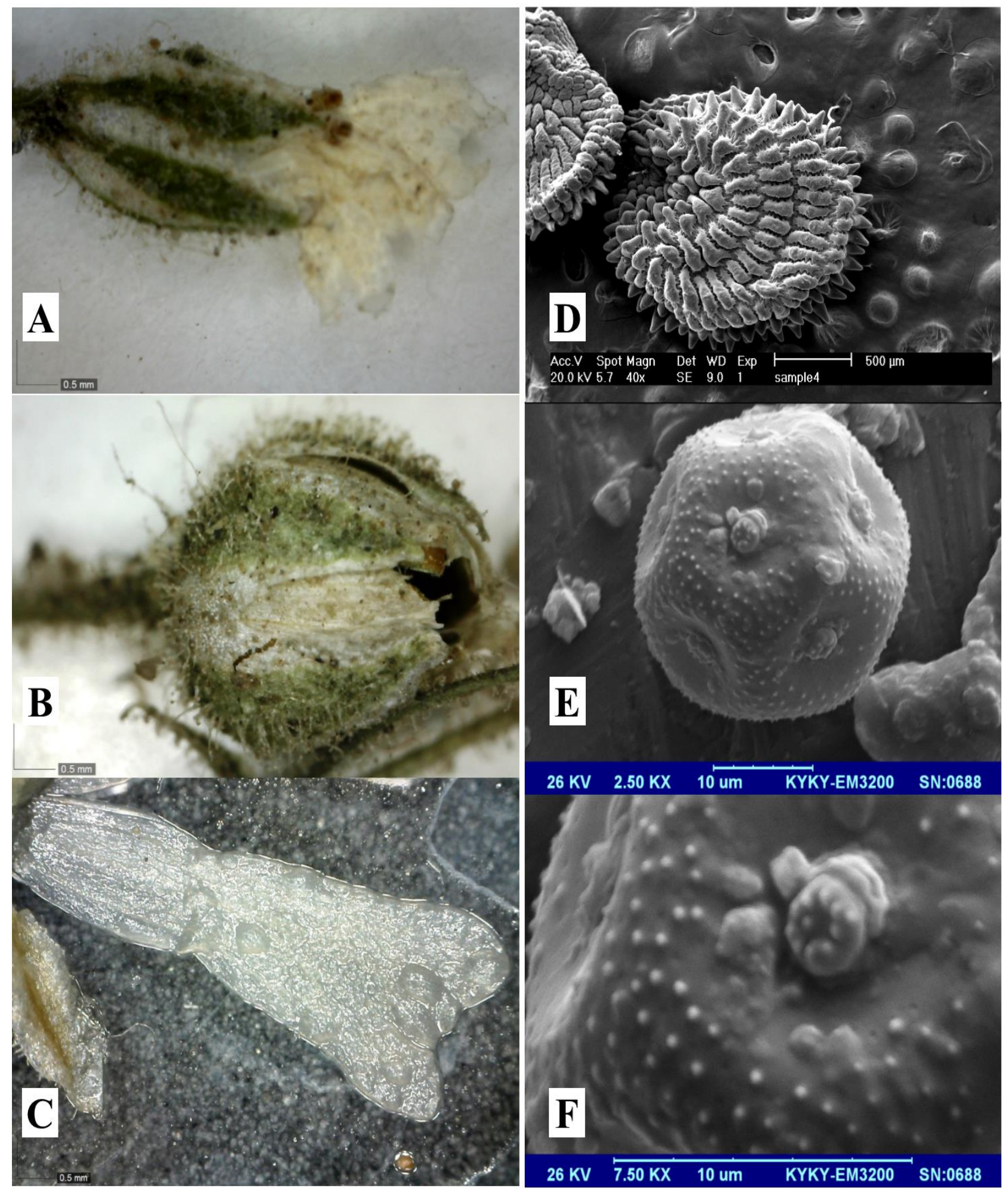

Fig. 3. Gypsophila hispida. A: Complete flower in side view, B: Fruit (capsule), C: petal, D: Scanning electron micrographs (SEM) of mature seed, E: Scanning electron micrographs (SEM) of pollen grain, F: Detail of pollen ornamentation (photos from V. Mozaffarian 69966 by A. Nejad Falatoury).

\section{CONCLUSION}

Subgenus Hagenia includes 6 taxa in Iran, which have some common morphological characteristics such as relatively elongated petals, foliaceus bracts and hairy calyxes except in $G$. pilosa var. glabra. In the following, an identification key for the six Iranian taxa of this subgenus is provided. 


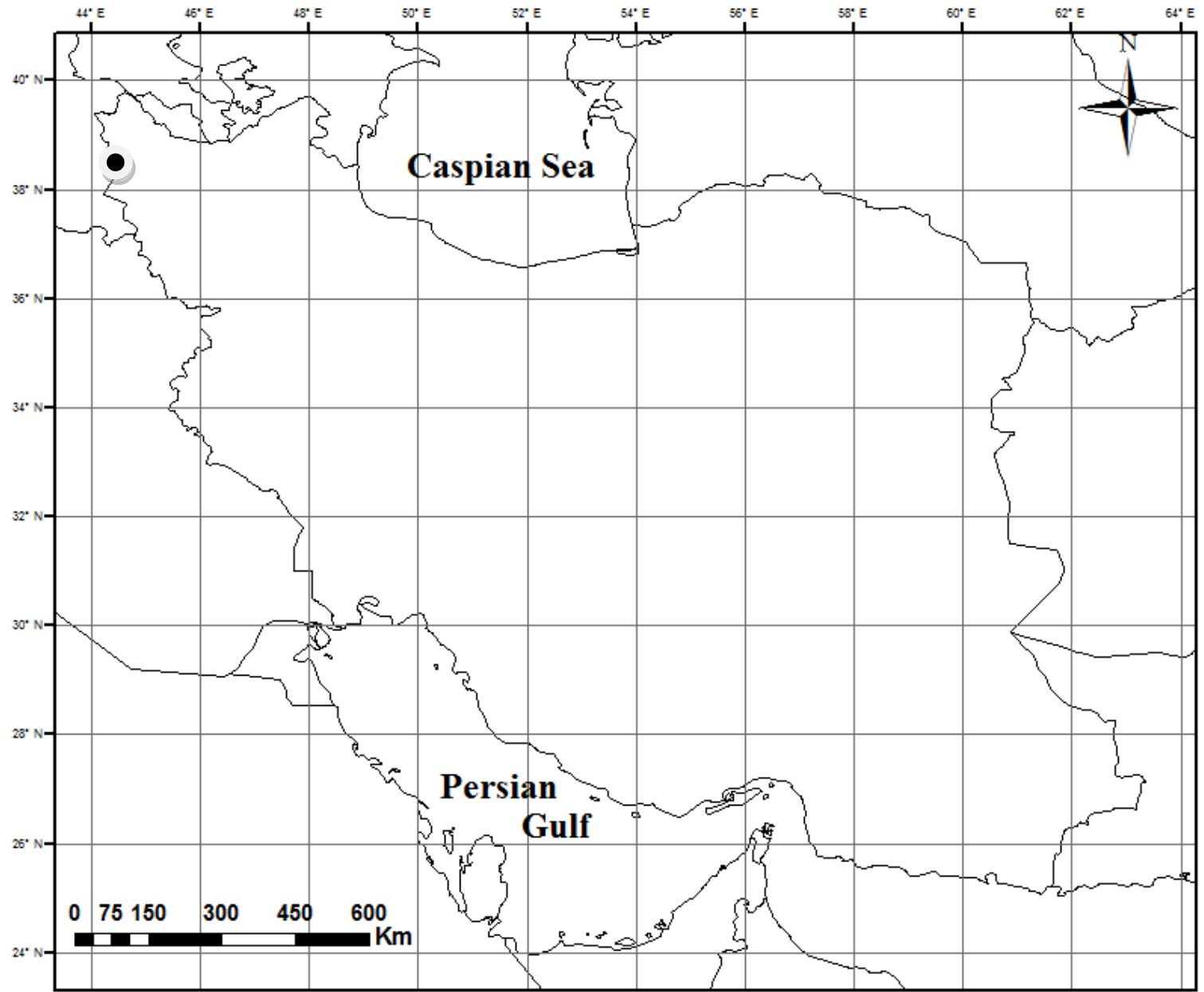

Fig. 4. Distribution map of Gypsophiala hispida in Iran.

A simplified key for the taxa of Gypsophila L. subgenus Hagenia (Moenche) Fenzl in Iran

1. Plant annual

\section{- Plant perennial}

2. Stem and calyces glandular-hairy G. pilosa Huds. var. pilosa Huds.

- Plant completely glabrous $G$. pilosa var. glabra Falat., F. Ghahrem. \& Assadi

3. Stem erect, middle leaves lanceolate to ovate 4

- Stem ascending to erect, middle leaves narrow lanceolate, petals spatulate, divided to distinctive lamina and claw, undulate

.G. farsensis Falat., Assadi \& F. Ghahrem.

4. Leaves oblanceolate to ovate, calyx $6-10 \mathrm{~mm}$, petals 11-17 mm, narrow cuneate, truncate G. platyphylla Boiss.

- Leaves lanceolate to spatulate, calyx 3-6 mm, petals $8-13 \mathrm{~mm}$, narrow cuneate, emarginate to sinuate 5

5. Lower leaves lanceolate, calyx 4-6 mm, petals pale yellow (cream), emarginate to sinuate

G. hispida Boiss.
- Lower leaves spatulate, calyx 3-4 mm, petals white with purple veins at base, emarginate .G. lurorum Rech.f.

\section{ACKNOWLEDGEMENT}

The authors are grateful to the curators of the herbaria TARI (Research Institute of Forests and Rangelands) and LE (Komarov Botanical Institute) for making the herbarium facilities available for the study. The First author would like to express the deepest appreciation to Prof. F. Ghahremaninejad for his valuable guide and support. Special thanks should be offered to A.H. Rezaee (Tehran) and M. Shojaei (Tehran) for their technical assistance.

\section{REFERENCES}

Amini, E., Zarre, Sh. and Assadi, M. 2011. Seed micro-morphology and its systematic significance in Gypsophila (Caryophyllaceae) and allied genera. Nord. J. Bot. 29: 660-669.

Armağan, M. 2016. Gypsophila munzurensis (Caryophyllaceae), a new species from Tunceli (Turkey). - Phytotaxa 275: 175-180. 
Armağan, M., Özgökçe, F. and Çelik, A. 2017. Notes on the genus Gypsophila (Caryophyllaceae) in Turkey, with a description of G. guvengorkii sp. nov. - Phytotaxa 295: 271-279.

Ataşlar, E. and Ocak, A. 2005. Gypsophila osmangaziensis (Caryophyllaceae), a new species from Central Anatolia, Turkey. - Ann. Bot. Fennici 42: 57-60.

Ataşlar, E. 2000. Gypsophila L. - In: Güner, A., Özhatay, N., Ekim, T. \& Başer, K. H. C. (eds.), Flora of Turkey and the East Aegean Islands, Suppl. 2, 11: 49-50. - Edinburgh University Press, Edinburgh.

Ataşlar, E., Potoğlu Erkara, I. and Tokur, S. 2009. Pollen morphology of some Gypsophila L. (Caryophyllaceae) species and its taxonomic value. Turk. J. Bot. 33: 335-351.

Barkoudah, Y.I. 1962. A Revision of Gypsophila, Bolanthus, Ankyropetalum and Phryna. - Wentia. 9: 1-203.

Boissier, E. 1843. Diagnoses plantarum orientalium novarum 1. - Lipsiae, apud B. Herrmann Genève. 76 pp.

Budak, Ü. 2012. Gypsophila yusufeliensis (Caryophyllaceae), a new species from Turkey. Ann. Bot. Fennici 49: 425-427.

Davis, P.H., Mill, R.R. and Tan, K. 1988. Gypsophila L. \& Silene L. - In: Davis, P.H., Mill, R.R. \& Tan, K. (eds), Flora of Turkey and the East Aegean Islands (Suppl. 1), Vol. 10 73-81. - Edinburgh University Press, Edinburgh, pp. 73-81.

Hamzaoğlu, E. 2012. A new species of Gypsophila and a new name for Silene (Caryophyllaceae) from Turkey. - Turk. J. Bot. 36: 135-139.

Huber-Morath, A. 1967. Gypsophila L. - In: Davis, P.H. (ed.), Flora of Turkey and the East Aegean Islands 2: 149-171. - Edinburgh Univ. Press, Edinburgh.

Hudson, W. 1766. A Catalogue of the Fifty Plants from Chelsea Garden, Presented to the Royal Society by the Worshipful Company of Apothecaries, for the Year 1765, Pursuant to the Direction of Sir Hans Sloane, Bart. Med. Reg. et Soc. Reg. Nuper Praeses: By William Hudson, Societatis Regiae \& Clariss. Societatis Pharmaceut. Lond. Soc. Hort. Chelsean. Praefectus et Praelector Botanic. - Philosophical Transactions: Giving Some Account of the Present Undertakings, Studies, and Labours of the Ingenious in Many Parts of the World. London 56: 250-258.

Koç, M. 2013. Gypsophila torulensis (Caryophyllaceae), a new species from Turkey. Ann. Bot. Fennici 50: $149-150$.

Linnaeus, C. 1753. Species Plantarum, Vol. 1. Laurentii Salvii, Stockholm, 560 pp.

Mabberley, D.J. 2008. Mabberley's Plant-Book third edition. - Cambridge University Press, New York, $383 \mathrm{pp}$.

Mozaffarian, V. 1991. New species and new plant records from Iran. - Iran. J. Bot. 5: 29-39.

Mozaffarian, V. (2008). Four new plant species from Ilam province, Iran. - Iran. J. Bot. 14: 87-94.

Nejad Falatoury, A., Assadi, M. and Ghahremaninejad, F. 2015a. A new species of
Gypsophila (Caryophyllaceae) from Iran. Phytotaxa 222: 276-282.

Nejad Falatoury, A., Assadi, M. and Ghahremaninejad, F. 2015b. Taxonomic significance of indumentum in the genus Gypsophila L. (Caryophyllaceae). Nova Biol. Reperta 2: 91-102.

Nejad Falatoury, A., Assadi, M. and Ghahremaninejad, F. 2016a. Gypsophila yazdiana (Caryophyllaceae), a new species from Iran. - Novon 24: 347-351.

Nejad Falatoury, A., Assadi, M. and Ghahremaninejad, F. 2016b. Gypsophila pseudopallida, a new species, and Gypsophila transcaucasica a new record of sect. Paniculaeformes from the North West of Iran. Phyton Ann. Rei Bot. 56: 1-13.

Nejad Falatoury, A., Assadi, M. and Ghahremaninejad, F. 2016c. New species and new synonymy in the genus Gypsophila L. subgenus Pseudosaponaria Williams (Caryophyllaceae). Adansonia 38: 257-265.

Nejad Falatoury, A., Ghahremaninejad, F. and Assadi, M. 2017. Palynological Study of the genus Gypsophila in Iran. - Rostaniha 18: 16-32.

Punt, W. and Hoen, P.P. 1995. The northwest European pollen flora, Caryophyllaceae, Review of paleobotany and palynology: 83-272. University of Utrecht the Netherlands.

Rabeler R.K. and Bittrich, V. 1993 Suprageneric nomenclature in the Caryophyllaceae. - Taxon 42: 857-863.

Rechinger, K.H. 1988. Gypsophila. - In: Rechinger, K.H. (ed.), Flora Iranica. Lfg. 163: 206-246. - Akad. Druck- und Verlagsanstalt, Graz.

Schischkin, B.K. 1936. Gypsophila L. - In: Komarov, V.L. (ed.) Flora of the U.S.S.R.6: 556-591. Izdatel'stvo Akademii Nauk SSSR, Moskva, Leningrad.

Yıldırıml, Ş. 2012. Nine new species from Kaz dağları, Munzur dağları, Bolkar dağları and Karçal dağları, Turkey. Ot Sis. Bot. Dergisi. 19: 1-34.

Yıldız, K. 2001. Pollen morphology of Caryophyllaceae species from Turkey. - Pak. J. Bot. 33: 329-355.

$$
* * * * *
$$

How to cite this article:

Nejad Falatoury, A. and Assadi, M. 2018. Gypsophila hispida, A New record for flora of Iran. - Nova Biol. Reperta 5 (3): 329-335. 